\title{
Volcanic Craters in the Libyan Desert
}

By Dr. K. S. SANDFORD

T $\mathrm{N}$ the last few weeks, reports of the occurrence 1 of volcanic craters in the Libyan desert have appeared in the daily Press. It seems wise, therefore, to define the discoveries more precisely as soon as possible, although detailed study of the material collected must be postponed for several weeks.

In the spring of 1932, the late Sir Robert Clayton East Clayton and Squadron-Leader Penderel, R.A.F., observed and photographed some crater-like hills between the Gilf Kebir and Gebel 'Uweinat, near the southern end of the Egyptian-Cyrenaican frontier. Sir Robert also flew over them with Mr. P. A. Clayton, of the Desert Survey of Egypt, who, with Count De Almàsy, was a member of the expedition. Some of their photographs appeared afterwards in the Illus-

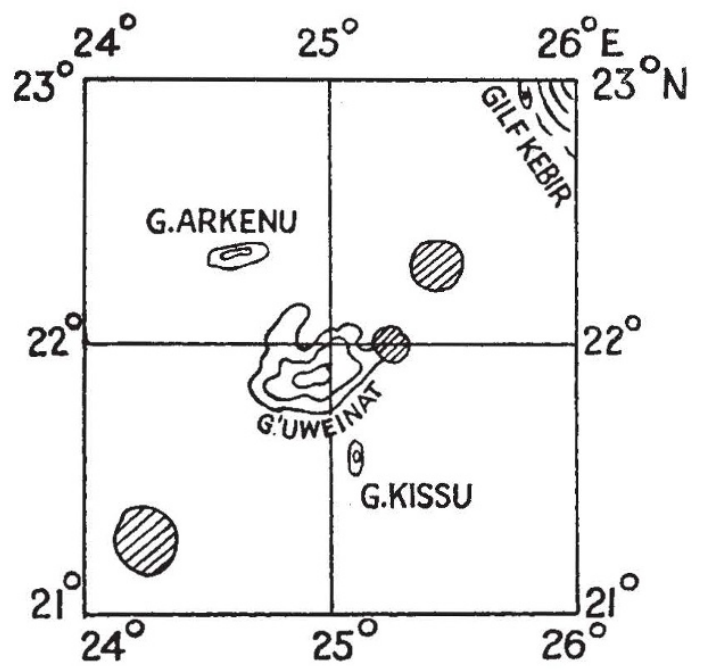

Trachyte, etc. Scale 1:4,000,000

Fta. 1.

trated London News, and Mr. Clayton has sent a paper on the western side of the Gilf Kebir to the Geographical Journal. The party was unable to visit the craters but their approximate position was computed.

In the first week of October 1932, Capt. Craig, R.E., W. B. K. Shaw, G. L. Prendergast and $I$ set out in a car from Gebel Kissu, the advanced base of the recent expedition led by Major R. A. Bagnold, and found the craters on the same day. Those previously seen from the air proved to be explosion craters; others, less obvious, were found to be the denuded stumps of volcanoes: both types were encircled by high ramparts of steeply tilted, hardened, and locally fused Nubian sandstone. Seven principal hills, standing 100-300 ft. above the plain, are grouped within a radius of about five miles, and to these must be added minor elevations and a thick horizontal sheet of 'lava' which caps a prominent hill nearby; this may have been a surface flow or a sill.

One of the best preserved of the explosion craters was about half a mile wide from east to west and about a quarter of a mile wide from north to south (inside measurements), with vertical walls of hardened Nubian sandstone rising 100-130 ft. above the plain. The centre, partly filled with sand and rubble, was at about the same level as the plain, and water flowing from it has cut a deep channel through the southern wall. Some of the craters evidently now contain lakes after the rare rains, and the remains of mountain sheep and other animals that came to them were common.

Within the main ramparts of at least two of the explosion craters were found subsidiary plugs of white trachytic rock, and adjacent to them the fusion of the sandstone walls was very marked. The relative ages of explosion and flow of molten rock in these multiple craters seemed to vary. Into the white rock had been intruded a dark basalt-like rock of much the same specific gravity as the trachyte: although both rocks varied appreciably in texture over the area, their mutual relation seemed to remain the same.

A noticeable feature of the whole neighbourhood was the presence of double walls of hardened sandstone, running on straight or curved courses over the surrounding plain and across some of the craters. These, and pipe-like tubes of irony sinter penetrating the unbroken Nubian sandstone of the plain, seem to have been formed by hot solutions at a late stage of the period of activity. In some, amorphous and gypseous substances occupied the space (usually four to six feet) between the parallel faces of the double walls.

During our reconnaissance from the craters to Gebel 'Uweinat, we found a similar but smaller area at the north-eastern corner of the massif. Here, in particular, prismatic sandstone, well-known to Messrs. H. J. L. Beadnell and P. A. Clayton from their surveys in adjacent areas, was intimately associated with the type of 'wall' already described.

At about this time, Squadron-Leader Penderel, who had followed our party out from the Nile valley by air, landed beside us and was kind enough to take specimens for me to Cairo, where they were given to $\mathrm{Mr}$. O. H. Little, director of the Geological Survey of Egypt. I am indebted to $\mathrm{Mr}$. Little for some notes which reached me on our arrival in Fasher several weeks later.

A considerable 'volcanic field' may, therefore, now be added to the map between the north-eastern cormer of 'Uweinat and about lat. $22^{\circ} 18^{\prime} \mathrm{N}$., long. $25^{\circ} 30^{\prime}$ E. A similar volcanic area, with trachytic rocks, was encountered on the south-western side of 'Uweinat during the investigation of the country 
westward to Sarra and the Tibesti foothills. It is centred about lat. $21^{\circ} 16^{\prime} \mathrm{N}$., long. $24^{\circ} 14^{\prime} \mathrm{E}$, with a radius of about six miles, and most of its denuded stumps were visited by Lieut. D. R. Paterson and myself. There seem to be no explosion craters in this group.

Each 'field' is associated with very slight folds of the Nubian sandstone, and the complex of ancient rocks upon which it lies is exposed in the immediate vicinity by the denudation of the slight surviving thickness of sandstone. The period of volcanicity is obviously far younger than the Nubian series, and the fresh appearance of the explosion craters suggests a fairly recent date of formation.

The discovery of a few stone implements of Middle Palæolithic type in and near some of the craters necessitates a readjustment of ideas, which is confirmed by comparison with the great crater of Malha, in the Meidob Hills about 150 miles north - north - east of Fasher. Malha seems to have exploded but yesterday: the basaltic lavas which surround it and have flowed into one corner of it are fresher than many on the flanks of Vesuvius, yet the traditions among the people who depend on the springs within it seem to recall only variations of level of the lake in its centre. These explosion craters seem to be far older than they at first appear.

The presence of light trachytic rocks within a radius of about 50 miles from Gebel 'Uweinat is of interest in contrast to the wide distribution of basalt and dolerite over Egypt and the Sudan, ranging from an Oligocene age in Egypt to at least a semi-recent age at Malha. About 'Uweinat the dolerites seems to be of far greater age than the features described above, but there was a later effusion of basaltic magma at Malha-the presence of basaltic lava and of 'volcanoes' in the Bayuda desert between Berber and Merowe (Dongola) will be recalled-probably long after the trachytes of 'Uweinat were cold.

\section{The Old Morphology and the New*}

By Dr. H. Hamshaw Thomas

"T HE full problem of morphology is . . . to explain how in the past plants came to be such as we now see them" (Bower). The problem is often regarded as insoluble, but a survey of the development of morphological concepts suggests that some of our difficulties may be due to the tacit acceptance of theories handed down by successive generations of teachers. In dealing with the flowering plants, almost all recent writers accept the classical concepts originated by Goethe and Lindley in pre-evolutionary days. During the last thirty years, however, a large body of facts has been accumulated about the simpler and older plants, and a new system of ideas has been founded, which is in harmony with our knowledge of the form of the earliest known Devonian land plants. We have now to face the question of the relation between the fundamental concepts of the old morphology and those of the new.

At the outset of any discussion of form, it is necessary to keep in mind the principles underlying our comparisons. In the past, before the coming of evolution, comparisons of plants were mainly subjective, but to-day we aim at an objective approach. Plants are objectively comparable because we consider them to be derived from common ancestors; if we reject the subjective approach, we must introduce phylogenetic considerations.

We owe the term 'morphology' and the foundation of the classical concepts to the poet philosopher, Goethe, who published in 1790 a treatise "On the Metamorphosis of Plants", which has been called "the foundation of all that has since been done in vegetable morphology". The most important conclusion in this essay is that "whether a

* From a paper raad to the Linnean Society of London on November 10,1932 . plant produces leaf-buds, flowers, or fruits it is still the same organ which is carrying Nature's laws into effect, though performing different offices and disguised under different forms". This one organ is called the leaf, but Goethe appeared to feel that it should be given some more generalised designation.

The spread of this doctrine in England was largely due to Lindley, who repeated Goethe's views and arguments, but he made an important modification in the theory which has received insufficient attention. Goethe wisely wrote near the close of his essay, "The thing now to be aimed at is to keep habitually in view the two contrary directions in which variations are developed. For we may say with equal truth that a stamen is a diminished petal or that a petal is an expanded stamen."

Lindley, however, concludes that "the leaf, as the first formed, the most perfect of all [the appendages] and that which is most constantly present, is properly considered the type from which all the others are derivations". 'This unsupported assumption was widely accepted, and Darwin in "The Origin of Species" spoke of the view that the parts of the flower consist of metamorphosed leaves as familiar to almost everyone. As the result of Darwin's work, the old concepts of the subjective and idealistic philosophers have been taken over and given an objective significance by biologists.

The doctrine of metamorphosis led to the idea that the parts of plants could be divided into three distinct eategories, stems, roots and leaves. This has met with less universal approval. It may be tenable when we are dealing only with the mostly highly evolved forms, but when an attempt is made to extend it downwards grave difficulties are encountered. It has resulted in an unnatural 